\title{
Performance Characteristics Optimization of Electrical Discharge Machining Process using Back Propagation Neural Network and Genetic Algorithm
}

\author{
Robert Napitupulu ${ }^{1}$, Arif Wahyudi ${ }^{1}$, and Bobby O.P Soepangkat ${ }^{1}$
}

\begin{abstract}
This study attempts to make a model and optimize the complicated Electrical Discharge Machining (EDM) process using soft computing techniques. Artificial Neural Network (ANN) with back propagation algorithm is used to model the process. In this study, the machining parameters, namely pulse current, on time, off time and gap voltage are optimized with considerations of multiple performance characteristics such as Metal Removal Rate (MRR) and surface roughness. As the output parameters are conflicting in nature so there is no single combination of cutting parameters, which provides the best machining performance. Genetic Algorithm (GA) with properly defined objective functions was then adapted to the neural network to determine the optimal multiple performance characteristics.
\end{abstract}

Keywords-Electrical discharge machining (EDM), Artificial neural network (ANN), Multiple performance characteristics, Genetic algorithm (GA).

Abstrak - Pada penelitian ini mencoba untuk membuat model dan mengoptimalkan proses yang rumit pada Electrical Discharge Machining (EDM) menggunakan teknik komputasi. Jaringan Saraf Tiruan (JST) dengan algoritma propagasi kembali digunakan untuk memodelkan proses. Dalam penelitian ini, parameter mesin, yaitu pulsa saat ini, tepat waktu, off waktu dan kesenjangan tegangan dioptimalkan dengan pertimbangan dari beberapa karakteristik kinerja seperti Metal Removal Rate (MRR) dan kekasaran permukaan. Sebagai parameter output bertentangan di alam sehingga tidak ada kombinasi tunggal parameter pemotongan, yang menyediakan kinerja mesin terbaik. Algoritma genetika (GA) dengan didefinisikan dengan baik fungsi obyektif kemudian disesuaikan dengan jaringan saraf untuk menentukan beberapa karakteristik kinerja yang optimal.

Kata Kunci-Distribusi Log-logistik, Momen, Kumulan, FungsiKarakteristik.

\section{INTRODUCTION}

log-logistic Electrical Discharge Machining (EDM) is Aone of the most extensively used non-conventional material removal or machining process. The unique feature of this process is the usage of thermal energy to machine electrically conductive parts regardless of hardness. This characteristic has become the distinctive advantage of EDM process in the manufacture of mould, die, automotive, aerospace and surgical component [1]. The selection of machining parameters for obtaining optimal responses is very much essential as this is a costly process to increase production rate considerably by reducing the machining time.

Material Removal Rate (MRR), surface roughness and tool wear are the most important response parameters in die-sinking EDM. Several researchers have conducted various investigations for improving the process performance [2-7]. Determination of proper machining parameters for obtaining the best process performance is still a challenging job. To solve this type of multioptimization problem Lin et al. [2] used Grey Relational Analysis (GRA) based on an orthogonal array and fuzzy based Taguchi method. Lin and Lin [3] used grey-fuzzy

${ }^{1}$ Robert Napitupulu, Arif Wahyudi, and Bobby O.P Soepangkat are with Departement of Mechanical Engineering, Faculty of Industrial Technology, Institut Teknologi Sepuluh Nopember, Surabaya, 60111, Indonesia. Email: r_na70@yahoo.co.id; arif_w@me.its.ac.id; bops_1994@me.its.ac.id. logic for the optimization of EDM sinking process, as the performance parameters are fuzzy in nature, such as higher the better (MRR) and lower the better (tool wear and surface roughness), and contain certain degree of uncertainty. Grey relational coefficient analyzes the relational degree of the multiple responses (material removal rate, surface roughness and electrode wear rate). Fuzzy logic is used to perform a fuzzy reasoning of the multiple performance characteristics.

Artificial Neural Networks (ANN) have been developed by using the current understanding of the biological nervous system, and considered to be highly flexible modeling tools with capabilities on learning the mathematical mapping between input variables and output features for nonlinear system [8]. The relationships between machining parameters of EDM such as current, pulse on time and pulse off time and MRR and tool wear have been developed by using Back Propagation Neural Network (BPNN) [9]. MRR model has also developed for EDM process using pulse on time, pulse off time, sparking frequency and gap current [10].

Wang et al. [4] used ANN with GA to determine the optimal machining parameters of EDM sinking for optimal performances. ANN is used to model the process, where weights are updated by GA. Gen-Hunter Software is used to solve multi-objective optimization problem in the optimization phase. Two output parameters, MRR and surface roughness are considered to be optimized as a process performance. Optimization 
of the EDM parameters has been done by $\mathrm{Su}$ et al. [5] and conducted from the rough cutting to the finish cutting stage.The relationship between the machining parameters and machining performance was established by using a trained neural network. GA with properly defined objective functions was then adapted to the neural network to determine the optimal machining parameters. Transformation of MRR, tool wear and surface roughness into a single objective was conducted by using a simple weighted method.

EDM process has been considered as complex and stochastic process [9]. It is difficult to determine the optimal EDM parameters for best machining performance such as productivity and accuracy. MRR and tool wear are two important output parameters which decide the cutting performance. But these performance parameters are conflicting in nature. The characteristic of MRR is the higher is better while the characteristic of tool wear is lower is better.

In a single objective optimization, there is only one solution. But in case of multiple objectives, there may not exist one solution, which is the best with respect to all objectives. In EDM process, it is not easy to obtain a single optimal combination of machining parameters for the performance parameters, as the machining parameters affect them differently. Classical methods for solving multi-objective problem have some drawbacks. Hence, there is a need for a multi-objective optimization method to arrive at the solutions to this problem. These methods transform the multi-objective problem into single objective by assigning some weights based on their relative importance [9]. These classical methods will also fail when the function becomes discontinuous.

Since GA is a good tool for solving multi-objective optimization and its works with a population of points, it seems natural to use multi-objective GA in EDM process to determine the optimal solution point from best performance to capture a number of solutions simultaneously [11]. In the present work, a hybrid of BPNN and GA has been used to obtain the optimal combination of machining parameters.

\section{METHOD}

\section{A. Material and Equipments}

In this study, an EDM machine Hitachi H-DS025 was used as the experimental machine. A rectangular copper was used as electrode to erode a workpiece of AISI 4140 with a diameter of $25 \mathrm{~mm}$. The schematic diagram of the experimental set-up is shown in Fig. 1. The w orkpiece and electrode were separated by a moving dielectric fluid such as kerosene.

\section{B. Artificial Neural Network (ANN)}

An ANN can be briefly described as an informationprocessing system that has certain performance characteristics in common with biological neural networks. According to Thillaivannan et al. [11], ANN have been developed as generalization of mathematical models of human cognition or neural biology based on the assumptions that:

a. The processing of information occurs at many elements called neurons.

b. Signals are passed between neurons over connection links. c. Each connection link has an associated weight, which, in a typical neural net, multiplies the signal transmitted.

d. An activation function (usually nonlinear) is applied by each neuron to its net input (sum of weighted input signals) to determine its output signal.

There are numerous studies that have been reported on the development of neural networks based on different architectures in the past decades. Basically, neural networks can be characterized by its important features, such as the architecture, the activation functions, and the learning algorithms. In general, each category of the neural networks would have its own input characteristics, and therefore it can only be applied for modeling some specific processes [11].

\section{1) Architecture}

In general, neural networks are categorized by their architecture. The convergence rate at the stage of training the network parameters is determined by the number of hiddeen layers. Since the number of neurons is typically assumed to be dominant in the networks, one hidden layer could be considered sufficient in the multilayered networks. Hence, the number of neurons must be determined by an optimization method [11]. MATLAB ${ }^{\circledR}$ software, which is a high-performance language for technical computing, can be used for modeling and developing of neural network.

\section{2) Activation Functions}

Signal links designated by corresponding weightings are used to connect the neurons. An internal state called the activation is representing each individual neuron. The activation is functionally dependent of the inputs. The sigmoid functions ( $\mathrm{S}$-shaped curves), such as logistic functions and hyperbolic tangent functions, are generally adopted for representing the activation. In the networks, a neuron sends its activation to the other neurons for information exchange via signal links [11].

3) Algorithm

There are numerous variations of the backpropagation algorithm. The simplest implementation of backpropagation learning updates the network weights and biases in the direction in which the performance function decreases most rapidly the negative of the gradient. One iteration of this algorithm can be written as

$\mathrm{X}_{\mathrm{k}+1}=\mathrm{X}_{\mathrm{k}}-\alpha_{\mathrm{k}} \mathrm{g}_{\mathrm{k}}$

where $\mathrm{Xk}+1$ is a vector of current weights and biases, $\mathrm{Xk}$ is the current gradient, and gk is the learning rate.

This algorithm can be implemented in two different ways, namely incremental mode and batch mode. In the incremental mode, the gradient is computed and the weights are updated after each input is applied to the network. In the batch mode all of the inputs are applied to the network before the weights are updated [11].

\section{4) Training}

There are two methods of backpropagation training algorithms, i.e., gradient descent and gradient descent with momentum [11]. The two methods are often too slow for practical problems. There are several high performance algorithms that can converge from ten to one hundred times faster than the aforementioned algorithms. All of the faster algorithms operate in the batch mode. There are two main categories of those faster algorithms. The first category uses heuristic techniques, which were developed from an analysis of the 
performance of the standard steepest descent algorithm. One heuristic modification is the momentum technique. There are two more heuristic techniques, i.e., variable learning rate backpropagation and resilient backpropagation.

\section{5) Backpropagation}

There are several applications of ANN such as BackPropagation Network (BPN) and a General Regression Neural Network (GRNN). In general, BPN can be considered as the most utilized neural network. The development of BPN represents a landmark in the history of neural networks because it provides a computationally efficient method for the training of the multi-layer perceptron [12]. A multi-layer perceptron trained with the back propagation algorithm may be viewed as a practical way of performing a non-linear input-output mapping of a general nature.

\section{Genetic Algorithm}

The development of GA was based on the probabilistic nature that the global optimum is searched in a random and parallel manner through operations of reproduction, crossover and mutation [13]. Many conventional optimization methods have the disadvantage of requiring derivatives of an objective function about the problem to be solved and become easily trapped into local minimum in the search scope [13].

There are three main operators in GA, i.e., selection, crossover and mutation [14]. Selection means that two individuals from the whole population of individuals are selected as "parents." Crossover serves to exchange the segments of selected parents between each other according to a certain probability. In other words, it combines two parents to form children for the next generation. The mutation operation randomly alternates the value of each element in a given chromosome according to the mutation probability. Mutation forms new children at random so as to avoid premature convergence. The procedure may be stopped after the terminated condition has been reached. Fig. 2 illustrates the solution procedure of GA.

\section{RESULT AND DISCUSSION}

An experiment was designed using Taguchi method [15], which uses an orthogonal array to study the entire parametric space with a limited number of experiments. The four EDM parameters (control factors) are pulse current, on time, off time and gap voltage. As shown in Table 1, one of them was set at two different levels while the other three were set at three different levels. Therefore, the total degrees of freedom were seven. $\mathrm{L}_{18}$ orthogonal array that used for the experiment is shown in Table 2 and led to a total 18 tests. A random order was also determined for running the tests.

\section{A. Transformation Data}

The data that would be used for input layer and output layer of the BPNN should be transformed in accordance with the interval of activation function. In this study, the sigmoid biner (logsig) and sigmoid bipolar (tansig) functions are adopted for representing the activation. Based on the sigmoid biner activation, the data should be in the interv al of $[0,1]$. But, the value of the data according to this activation function are greater than 0 or less than 1. Hence, the data are transformed into the interval of $[0.1,0.9]$ [16]. The transformation is also conducted based on the quality characteristics of the responses.

Since the quality characteristic of MRR (larger is better) is opposite of the quality characteristic of surface roughness (smaller is better), the transformation of the input parameters (pulse current, on time, off time and gap voltage) and surface roughness are conducted by using the following equation:

$(k)=0.1+0.8 \frac{X_{i}(k)-\min X_{i}(k)}{\max X_{i}(k)-\min X_{i}(k)}$

$X_{i}^{*}(k)$ is the transformed values of machining parameters and responses. Min $X_{i}(k)$ is the smallest value of $X_{i}(k)$ for the $k^{\text {th }}$ response and $\max X_{i}(k)$ is the largest value of $X_{i}(k)$ for the $k^{\text {th }}$ response.

Table 3 shows the result of the transformation of each input parameters, MRR and surface roughness which would be used as the input and output parameters in developing BPNN based prediction model. In this study, MATLAB version R210a is used as a computing software.

\section{1) Architecture of BPNN}

In this study, the varied parameters or factors for developing BPNN are:

a. The number of hidden layer: 1 and 2 .

b. The number of neuron in each hidden layer: 8 and 10 .

c. Activation function: logsig and tansig.

d. Training method: trainlm and trainrp.

An experiment using $2^{4}$ full factorial design is conducted to determine the combination of parameters or factors which which could give the smallest Mean Square Error (MSE). Table 4 shows 16 combinations of parameters used to develop BPNN network. This experiment uses learning rate 0.1 and the performance goal is $1 \mathrm{e}^{-10}$.

\section{2) Training, Testing and Validation}

Generally, in developing the prediction model based on BPNN, the percentages of the data used for training, testing and validation are $70 \%, 15 \%$ and $15 \%$ respectively. Figure 3 shows the MSE of the training using the first network which consists of eight neurons, one hidden layer, logsig type of activation function and trainlm type of training function. The output type is purelin. The MSE obtained after training 16 networks are shown in Figure 4. The sixth network of the network architecture 4-8-8-2 with logsig activation function and trainrp training type has the smallest value of MSE, i.e., 0.00852. Network architecture 4-8-8-2 implies 4-input layer, 2-hidden layer with 8 neurons in each hidden layer and 2-output layer, and shown in Fig. 5.

3) Optimization of GA-based BPNN (GA-BPNN)

The setting parameters of optimization are as follows:

a. Population size $=500$

b. Crossover probability $=0.6$

c. Generation $=60$

d. Mutation probability $=0.05$

e. Initial $=[0 ; 1]$

Optimization for obtaining maximum MRR and minimum surface roughness is conducted by using the following steps:

a. Compute the least average value of MRR and surface roughness. 
Table 3 shows that values of MRR and surface roughness of the $10^{\text {th }}$ combination of machining parameters are 0.3634 and 0.141 respectively. Hence, the least average value of MRR and surface roughness can be calculated as follows:

Mean $=\frac{\text { Average } M R R+\text { average surface roughness }}{2}$ 2

Mean $=\frac{0.3634+0.141}{2}$

Mean $=0.2520$

Enter the above value into MATLAB software version R2010a.

1. Run the program which would be terminated if:

a. The total number of generation (60) or maximum iteration has been achieved.

b. The best fitness value has been achieved.

The result shows that the average value of MRR and surface roughness of the $348^{\text {th }}$ combination of machining parameters is 0.1489 , lower than the initial value of the average of MRR and surface roughness, i.e., 0.2520. Table 5 shows the result of the GA-BPNN optimization of MRR and surface roughness.

4) Verification

Verification experiment is conducted by using the combination of the machining parameters resulted from GA-BPNN as shown in Table 6 with five replications. The result of the verification experiment then compared to the result of the $10^{\text {th }}$ combination of machining parameters of the initial experiment. Table 7 shows the comparison of the results of verification experiment and initial experiment.

Table 7 shows that the average of MRR and surface roughness resulted by the verification experiment $(0.136)$ is lower than the average of MRR and surface roughness resulted by the initial experiment $(0.252)$. This result has proven that the optimum setting of EDM sinking

machining parameters could give a better MRR and surface roughness than the initial setting.

Two-sample t-test is conducted to determine whether the MRR of verification experiment is larger than the MRR of initial experiment, and the surface roughness of verification experiment is smaller than the surface roughness of initial experiment. The followings are the hypothesis of the statistical tests for:

a. MRR

$\mathrm{H}_{0}$ : The average of MRR of initial experiment $=$ the average of MRR of verification experiment

$\mathrm{H}_{1}$ : The average of MRR of initial experiment $<$ the average of MRR of verification experiment

b. Surface roughness

$\mathrm{H}_{0}$ : The average of surface roughness of initial experiment $=$ the average of surface roughness of verification experiment

$\mathrm{H}_{1}$ : The average of surface roughness of initial experiment $>$ the average of surface roughness of verification experiment.

The results of the two-sample t-test are shown in Table 8. The optimum setting of the EDM sinking machining parameters resulted from the BPNN-GA optimization is gap voltage at 9 volt, off time at $21 \mu \mathrm{s} \mathrm{s}$, on time at $50 \mu \mathrm{s}$ and pulse current at 25 ampere. The result of the hypothesis test of MRR concludes that the average of MRR of initial experiment is the same with the average of MRR of verification experiment. Table 9 shows that the optimum setting of EDM sinking machining parameters produces more precise values of MRR than the initial setting. Therefore, even though those two averages are statistically the same, it can be concluded that the optimum setting would produce a higher MRR. As shown in Table 9, MRR is increased from 19.5 to $27.077 \mathrm{~mm}^{3} / \mathrm{min}$ and SR is decreased from 2.51 to 2.25 $\mu \mathrm{m}$.

\section{CONCLUSION}

The paper has presented the use of the combination of Back Propagation Neural Network (BPNN) and Genetic Algorithm (GA) for the optimization of EDM sinking process with multiple performance characteristics. A verification experiment has been conducted to confirm the results of this approach. As a result, the optimization methodology developed in this study is useful in improving multiple performance characteristics in the EDM sinking process. The setting of the EDM sinking parameters which produce the maximum MRR and the lowest surface roughness is gap voltage at 9 volt, off time at $21 \mu \mathrm{s} \mathrm{s}$, on time at $50 \mu \mathrm{s}$ and pulse current at 25 ampere.

\section{REFERENCES}

[1] Shankar Singh, S Maheshwari, and P C Pandey, "Some Investigations into The Electric Discharge Machining of Hardened Tool Steel using Different Electrode Materials," Journal of Material Processing Technology, vol. 149, no. 1-3, pp. 272-277, June 2004.

[2] C L Lin, J L Lin, and T C Ko, "Optimisation of The EDM Process Based on The Orthogonal Array with Fuzzy Logic and Grey Relational Analysis Method," International Journal of Advanced Manufacturing Technology, vol. 19, no. 4, pp. 271277, February 2002.

[3] J L Lin and C L Lin, "The use of Grey-Fuzzy Logic for The Optimization of The Manufacturing Process," Journal of Materials Processing Technology, vol. 160, no. 1, pp. 9-14, March 2005.

[4] Kesheng Wang, Hirpa L Gelgele, Yi Wang, Qingfeng Yuan, and Minglung Fang, "A Hybrid Intelligent Method for Modelling The EDM Process," International Journal of Machine Tools and Manufacture, vol. 43, no. 10, pp. 995-999, August 2003.

[5] J C Su, J K Kao, and Y S Tarng, "Optimisation of The Electrical Discharge Machining Process using a GA-Based Neural Network," The International Journal of Advanced Manufacturing Technology, vol. 24, no. 1, p. July, July 2004.

[6] Shajan Kuriakose and M S Shunmugam, "Multi-objective Optimization of Wireelectro Discharge Machining Process by Non-Dominated Sorting Genetic Algorithm," Journal of Materials Processing Technology, vol. 170, no. 1-2, pp. 133141, December 2005.

[7] Cao Fenggou and Yang Dayong, "The Study of High Efficiency and intelligent Optimization System in EDM Sinking Process," Journal of Materials Processing Technology, vol. 149, no. 1-3, pp. 83-87, June 2004.

[8] Jun Qu and Albert J Shih, "Development of The Cylindrical Wire Electrical Discharge Machining Process, Part I: Concept, Design, and Material Removal Rate," Journal of Manufacturing Science and Engineering, vol. 124, pp. 237-244, August 2002.

[9] Debabrata Mandal, Surjya K Pal, and Partha Saha, "Modeling of Electrical Discharge Machining Process using Back Propagation Neural Network and Multi-Objective Optimization using NonDominating Sorting Genetic Algorithm-II," Journal of Materials Processing Technology, vol. 186, no. 1-3, pp. 154-162, May 2007.

[10] A Yahya, T Andromeda, A Baharom, A A Rahim, and N Mahmud, "Material Removal Rate Prediction of Electrical Discharge Machining Process using Artificial Neural Network," Journal of Mechanics Engineering and Automation, vol. 1, pp. 298-300, 2011 
[11] A Thillaivanan, P Asokan, K N Srinivasan, and R Saravanan, "Optimization of Operating Parameters for EDM Process Based on The Taguchi Method and Artificial Neural Network," Int. Journal of Engineering Science and Technology, vol. 2, no. 12, pp. 6880-6888, 2010 .

[12] S Purushothaman and Y G Srivinisa Y, "A Back-Propogation Algorithm Applied to Tool Wear Monitoring," International Journal of Machine Tools and Manufacture, vol. 34, no. 5, pp. 625-631, July 1994.

[13] D E Goldberg, Genetic Algorithm in Search, Optimization, and Machine Learning. Boston, USA: ddison-Wesley Longman Publishing Co., Inc, 1989.

[14] Mitsuo Gen and Runwei Cheng, Genetic Algorithm and Engineering Design. New York, USA: John Wiley \& Sons, 1997.
[15] S H Park, Robust Design and Analysis for Quality Engineering, 1st ed.: Springer, 1996.

[16] C Ahilan, Somasundaram Kumanan, N Sivakumaran, and J Edwin R Dhas, "Modeling and Prediction of Machining Quality in CNC Turning Process using Intelligent Hybrid Decision Making Tools," Applied Soft Computing, vol. 13, no. 3, pp. 1543-1551, March 2013.

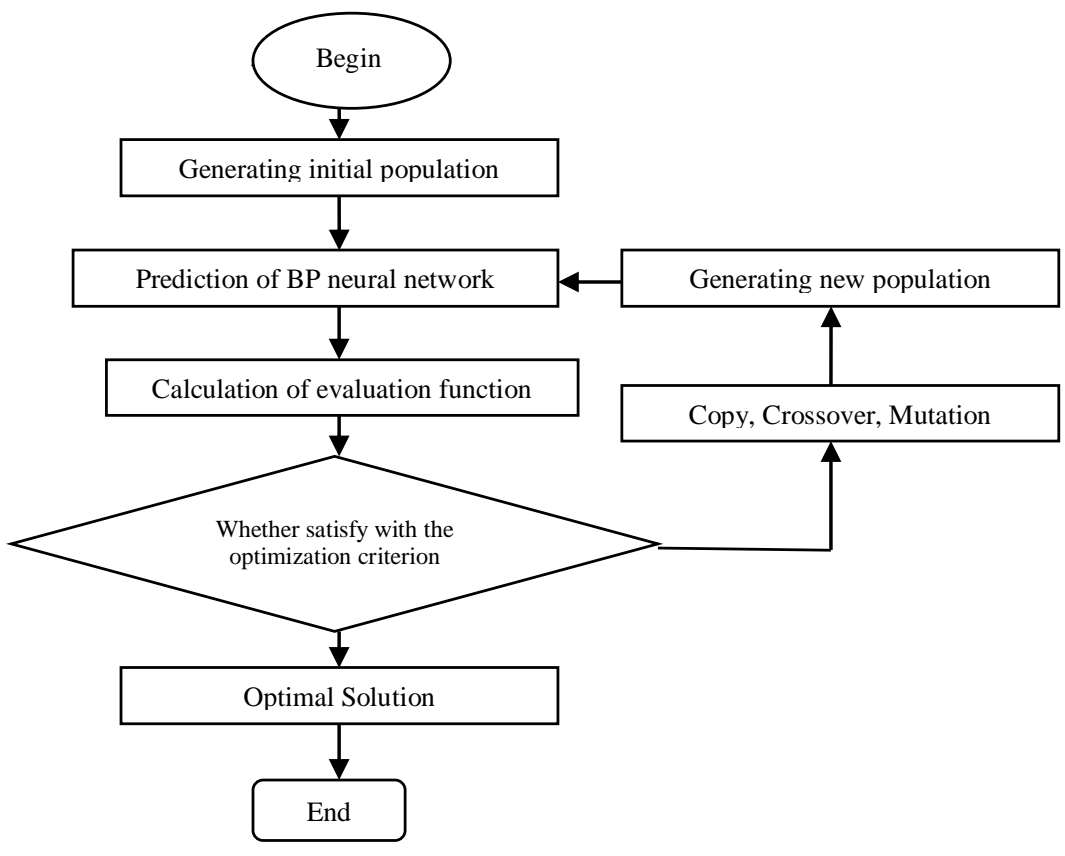

Figure 1. The solution procedure of GA

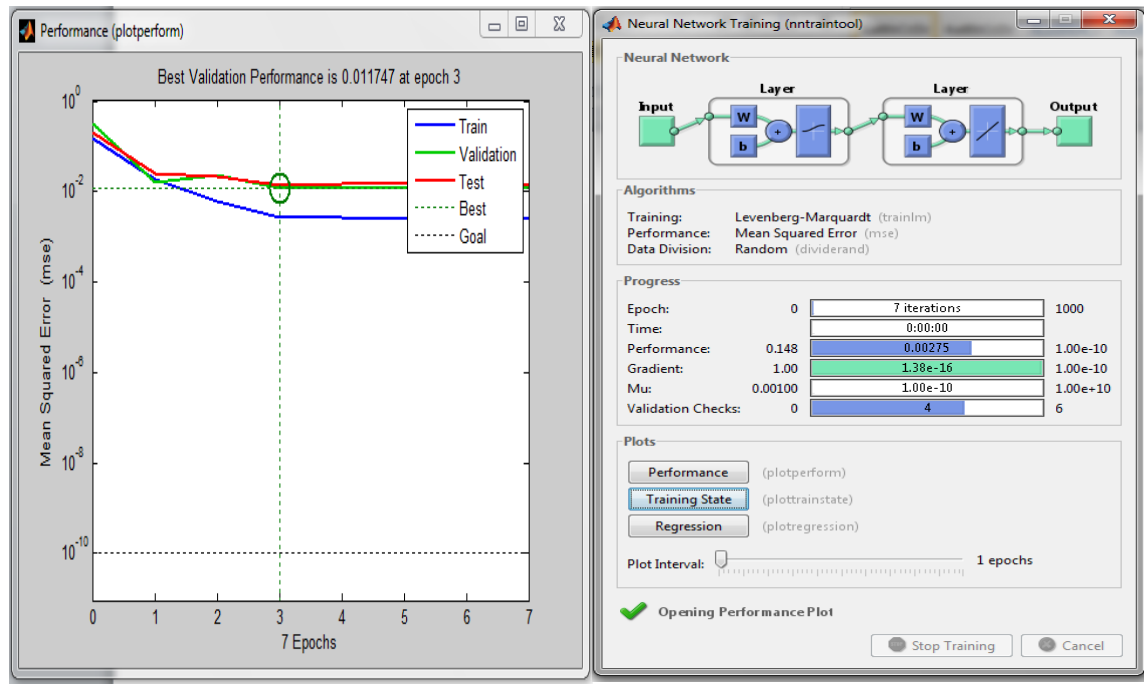

Figure 2. The MSE of the training 


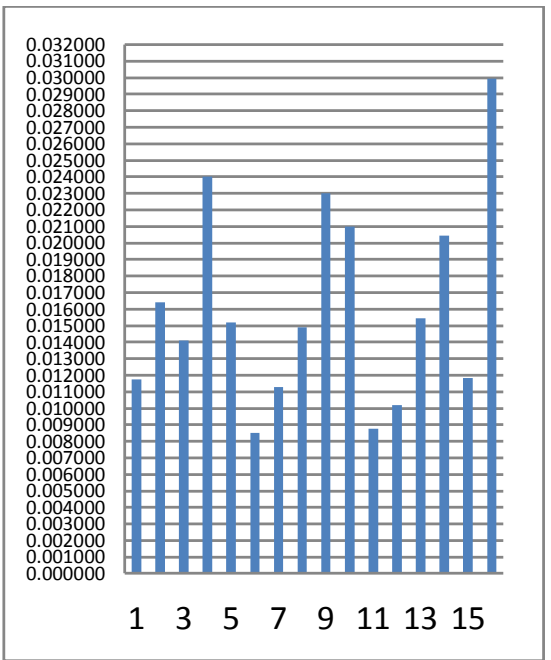

Figure 3. The MSE after training 16 networks

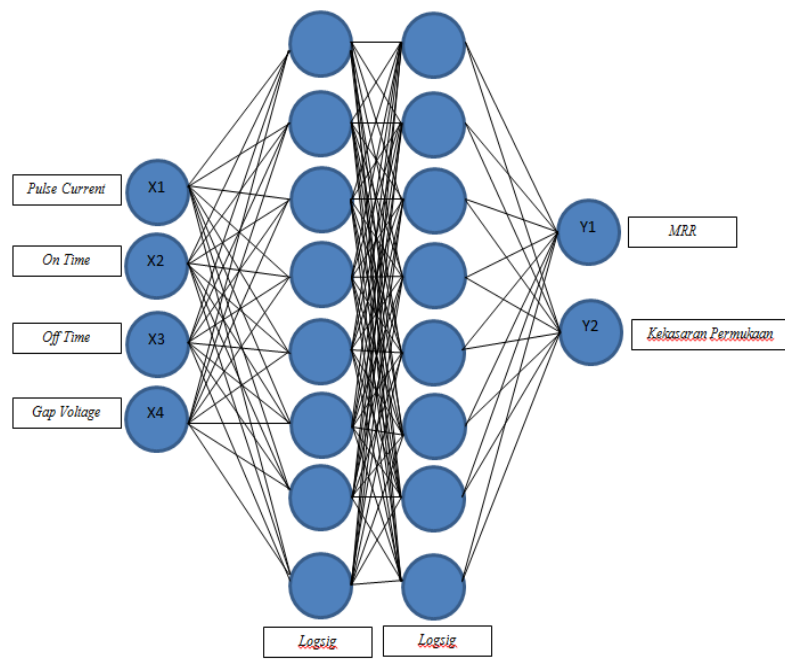

Figure 5. BPNN network architecture used for modeling.

TABLE 1.

MACHINING PARAMETERS AND THEIR LEVELS

\begin{tabular}{lllccc}
\hline \hline & \multicolumn{2}{c}{ Machining Parameters } & level 1 & level 2 & level 3 \\
\hline A & Gap voltage $(\mathrm{GV})$ & Volt & 8 & - & 10 \\
$\mathrm{~B}$ & Off time $(\mathrm{OFF})$ & $\mu \mathrm{s}$ & 21 & 23 & 25 \\
$\mathrm{C}$ & On time $(\mathrm{ON})$ & $\mu \mathrm{s}$ & 50 & 100 & 150 \\
$\mathrm{D}$ & Pulse Current $(\mathrm{PC})$ & Ampere & 15 & 20 & 25 \\
\hline \hline
\end{tabular}

TABLE 2.

ORTHOGONAL ARRAY L $\mathrm{L}_{18}$

\begin{tabular}{ccccc}
\hline \hline $\begin{array}{c}\text { Run } \\
\text { Order }\end{array}$ & $\begin{array}{c}\text { Gap } \\
\text { voltage } \\
(\text { Volt })\end{array}$ & $\begin{array}{c}\text { Off time } \\
(\boldsymbol{\mu s})\end{array}$ & $\begin{array}{c}\text { On time } \\
(\boldsymbol{\mu s})\end{array}$ & $\begin{array}{c}\text { Pulse } \\
\text { Current } \\
\text { (Ampere })\end{array}$ \\
\hline 1 & 8 & 21 & 50 & 15 \\
2 & 8 & 23 & 100 & 15 \\
3 & 8 & 25 & 150 & 15 \\
4 & 8 & 21 & 50 & 20 \\
5 & 8 & 23 & 100 & 20 \\
6 & 8 & 25 & 150 & 20 \\
7 & 8 & 21 & 50 & 25 \\
8 & 8 & 23 & 100 & 25 \\
9 & 8 & 25 & 150 & 25 \\
10 & 10 & 21 & 50 & 15 \\
11 & 10 & 23 & 100 & 15 \\
12 & 10 & 25 & 150 & 15 \\
13 & 10 & 21 & 50 & 20 \\
14 & 10 & 23 & 100 & 20 \\
15 & 10 & 25 & 150 & 20 \\
16 & 10 & 21 & 50 & 25 \\
17 & 10 & 23 & 100 & 25 \\
18 & 10 & 25 & 150 & 25 \\
\hline \hline
\end{tabular}


IPTEK, The Journal for Technology and Science, Vol. 25, No. 3, December 2014

TABLE 3.

THE RESULT OF THE TRANSFORMATION OF EACH INPUT PARAMETERS

\begin{tabular}{|c|c|c|c|c|c|c|c|c|c|c|c|c|c|}
\hline $\begin{array}{c}\text { Run } \\
\text { Order }\end{array}$ & $\begin{array}{c}\text { Gap } \\
\text { Voltage }\end{array}$ & $\begin{array}{c}\text { Off } \\
\text { Time }\end{array}$ & $\begin{array}{c}\text { On } \\
\text { Time }\end{array}$ & $\begin{array}{l}\text { Pulse } \\
\text { Current }\end{array}$ & MRR & $\begin{array}{c}\text { Surface } \\
\text { Roughness }\end{array}$ & $\begin{array}{c}\text { Run } \\
\text { Order }\end{array}$ & $\begin{array}{c}\text { Gap } \\
\text { Voltage }\end{array}$ & $\begin{array}{c}\text { Off } \\
\text { Time }\end{array}$ & $\begin{array}{c}\text { On } \\
\text { Time }\end{array}$ & $\begin{array}{c}\text { Pulse } \\
\text { Current }\end{array}$ & MRR & $\begin{array}{c}\text { Surface } \\
\text { Roughness }\end{array}$ \\
\hline 1 & 0.100 & 0.100 & 0.100 & 0.100 & 0.8809 & 0.1290 & 1 & 0.100 & 0.100 & 0.100 & 0.100 & 0.9 & 0.142 \\
\hline 2 & 0.100 & 0.100 & 0.500 & 0.500 & 0.6358 & 0.3310 & 2 & 0.100 & 0.100 & 0.500 & 0.500 & 0.6606 & 0.321 \\
\hline 3 & 0.100 & 0.100 & 0.900 & 0.900 & 0.3908 & 0.3660 & 3 & 0.100 & 0.100 & 0.900 & 0.900 & 0.5183 & 0.492 \\
\hline 4 & 0.100 & 0.500 & 0.100 & 0.100 & 0.7516 & 0.3930 & 4 & 0.100 & 0.500 & 0.100 & 0.100 & 0.7911 & 0.217 \\
\hline 5 & 0.100 & 0.500 & 0.500 & 0.500 & 0.6386 & 0.5200 & 5 & 0.100 & 0.500 & 0.500 & 0.500 & 0.5959 & 0.4 \\
\hline 6 & 0.100 & 0.500 & 0.900 & 0.900 & 0.2895 & 0.6240 & 6 & 0.100 & 0.500 & 0.900 & 0.900 & 0.3726 & 0.601 \\
\hline 7 & 0.100 & 0.900 & 0.100 & 0.500 & 0.5529 & 0.4920 & 7 & 0.100 & 0.900 & 0.100 & 0.500 & 0.6181 & 0.443 \\
\hline 8 & 0.100 & 0.900 & 0.500 & 0.900 & 0.3506 & 0.4470 & 8 & 0.100 & 0.900 & 0.500 & 0.900 & 0.4477 & 0.422 \\
\hline 9 & 0.100 & 0.900 & 0.900 & 0.100 & 0.7859 & 0.4000 & 9 & 0.100 & 0.900 & 0.900 & 0.100 & 0.7784 & 0.549 \\
\hline 10 & 0.900 & 0.100 & 0.100 & 0.900 & 0.4526 & 0.1180 & 10 & 0.900 & 0.100 & 0.100 & 0.900 & 0.2741 & 0.163 \\
\hline 11 & 0.900 & 0.100 & 0.500 & 0.100 & 0.7858 & 0.1000 & 11 & 0.900 & 0.100 & 0.500 & 0.100 & 0.6088 & 0.202 \\
\hline 12 & 0.900 & 0.100 & 0.900 & 0.500 & 0.4973 & 0.3380 & 12 & 0.900 & 0.100 & 0.900 & 0.500 & 0.6163 & 0.289 \\
\hline 13 & 0.900 & 0.500 & 0.100 & 0.500 & 0.502 & 0.1700 & 13 & 0.900 & 0.500 & 0.100 & 0.500 & 0.4839 & 0.389 \\
\hline 14 & 0.900 & 0.500 & 0.500 & 0.900 & 0.4075 & 0.5200 & 14 & 0.900 & 0.500 & 0.500 & 0.900 & 0.1966 & 0.396 \\
\hline 15 & 0.900 & 0.500 & 0.900 & 0.100 & 0.7093 & 0.3330 & 15 & 0.900 & 0.500 & 0.900 & 0.100 & 0.7475 & 0.421 \\
\hline 16 & 0.900 & 0.900 & 0.100 & 0.900 & 0.3676 & 0.2800 & 16 & 0.900 & 0.900 & 0.100 & 0.900 & 0.1 & 0.367 \\
\hline 17 & 0.900 & 0.900 & 0.500 & 0.100 & 0.7527 & 0.2740 & 17 & 0.900 & 0.900 & 0.500 & 0.100 & 0.8447 & 0.221 \\
\hline 18 & 0.900 & 0.900 & 0.900 & 0.500 & 0.3986 & 0.9000 & 18 & 0.900 & 0.900 & 0.900 & 0.500 & 0.5715 & 0.736 \\
\hline
\end{tabular}

TABLE 4.

COMBINATIONS OF PARAMETERS USED TO DEVELOP BPNN NETWORK.

\begin{tabular}{ccccc}
\hline \hline Network & $\begin{array}{c}\text { Neuron } \\
\text { Unit }\end{array}$ & $\begin{array}{c}\text { Hidden } \\
\text { Layer }\end{array}$ & $\begin{array}{c}\text { Activation } \\
\text { function }\end{array}$ & $\begin{array}{c}\text { Training } \\
\text { function }\end{array}$ \\
\hline 1 & 8 & 1 & logsig & trainlm \\
2 & 8 & 1 & logsig & trainrp \\
3 & 8 & 1 & tansig & trainlm \\
4 & 8 & 1 & tansig & trainrp \\
5 & 8 & 2 & logsig & trainlm \\
6 & 8 & 2 & logsig & trainrp \\
7 & 8 & 2 & tansig & trainlm \\
8 & 8 & 2 & tansig & trainrp \\
9 & 10 & 1 & logsig & trainlm \\
10 & 10 & 1 & $\operatorname{logsig}$ & trainrp \\
11 & 10 & 1 & tansig & trainlm \\
12 & 10 & 1 & tansig & trainrp \\
13 & 10 & 2 & logsig & trainlm \\
14 & 10 & 2 & logsig & trainrp \\
15 & 10 & 2 & tansig & trainlm \\
16 & 10 & & tansig & trainrp \\
\hline \hline
\end{tabular}

TABLE 5 .

THE RESULT OF THE GA-BPNN OPTIMIZATION OF MRR AND SURFACE ROUGHNESS.

\begin{tabular}{|c|c|c|c|c|c|c|}
\hline $\begin{array}{c}\text { Combination } \\
\text { of machining } \\
\text { parameters }\end{array}$ & \multicolumn{4}{|c|}{ Machining Parameters } & \multicolumn{2}{|c|}{ Responses } \\
\hline 348 & 0.42695 & 0.10334 & 0.17831 & 0.89976 & 0.16457 & 0.13339 \\
\hline 348 & 88.174 & 213.916 & 504.178 & 249.971 & 34.135 & 48.551 \\
\hline
\end{tabular}


TABLE 6.

THE RESULT OF THE VERIFICATION EXPERIMENT

\begin{tabular}{|c|c|c|c|c|c|}
\hline \multicolumn{4}{|c|}{ Machining Parameters } & \multicolumn{2}{|c|}{ Responses } \\
\hline $\begin{array}{c}\text { Gap } \\
\text { Voltage } \\
\text { (V) }\end{array}$ & $\begin{array}{c}\text { Off Time } \\
(\mu \mathrm{s})\end{array}$ & $\begin{array}{c}\text { On Time } \\
(\mu \mathrm{s})\end{array}$ & $\begin{array}{l}\text { Pulse } \\
\text { Current } \\
\text { (A) }\end{array}$ & $\operatorname{MRR}\left(\mathbf{m m}^{3} / \mathbf{m i n}\right)$ & $\begin{array}{l}\text { Surface Roughness } \\
\qquad(\mu \mathrm{m})\end{array}$ \\
\hline \multirow{6}{*}{9} & \multirow{5}{*}{21} & \multirow{5}{*}{50} & \multirow{5}{*}{25} & 34.116 & 4.56 \\
\hline & & & & 34.124 & 4.52 \\
\hline & & & & 34.151 & 4.54 \\
\hline & & & & 34.132 & 4.82 \\
\hline & & & & 34.118 & 4.70 \\
\hline & \multicolumn{2}{|c|}{ Average } & & 34.128 & 4.63 \\
\hline
\end{tabular}

TABLE 7.

THE RESULT OF THE VERIFICATION EXPERIMENT

\begin{tabular}{cccccc}
\hline \hline & \multicolumn{2}{c}{ Responses } & $\begin{array}{c}\text { Transformed Responses } \\
\text { Surface } \\
\text { MRR }\left(\mathbf{m m}^{3} / \mathbf{m i n}\right)\end{array}$ & $\begin{array}{c}\text { Surface roughness } \\
(\boldsymbol{\mu m})\end{array}$ & Average \\
\hline Verification & 34.116 & 4.56 & 0.1652 & 0.100 & 0.133 \\
experiment & 34.124 & 4.52 & 0.1649 & 0.095 & 0.130 \\
& 34.151 & 4.54 & 0.1641 & 0.098 & 0.131 \\
& 34.132 & 4.82 & 0.1647 & 0.130 & 0.147 \\
& 34.118 & 4.70 & 0.1651 & 0.116 & 0.141 \\
Average & 34.1282 & 4.628 & 0.1648 & 0.1078 & 0.136 \\
Initial & 24.45 & 4.72 & 0.453 & 0.118 & 0.285 \\
experiment & 30.45 & 5.12 & 0.274 & 0.163 & 0.219 \\
Average & 27.45 & 4.92 & 0.3635 & 0.1405 & 0.252 \\
\hline \hline
\end{tabular}

TABLE 8.

THE RESULT OF THE TRANSFORMATION OF EACH INPUT PARAMETERS

\begin{tabular}{cccc}
\hline \hline Responses & p-value & $\mathbf{H}_{\mathbf{0}}$ & Average \\
\hline MRR & 0.866 & Fail to reject & $\mu_{1}=\mu_{2}$ \\
Surface roughness & 0.048 & Rejected & $\mu_{1}>\mu_{2}$ \\
\hline
\end{tabular}

TABLE 9.

THE COMPARISON OF THE RESULTS OF VERIFICATION EXPERIMENT AND INITIAL EXPERIMENT.

\begin{tabular}{|c|c|c|c|c|}
\hline & \multirow{2}{*}{ Initial } & \multicolumn{2}{|c|}{ Optimal Process Condition } & \multirow{7}{*}{ Improvement } \\
\hline & & Prediction & Verification & \\
\hline \multirow{5}{*}{$\begin{array}{l}\text { Level of machining } \\
\text { parameters }\end{array}$} & GV (10 volt) & GV (9 volt) & GV (9 volt) & \\
\hline & & & & \\
\hline & OFF $(21 \mu s)$ & OFF $(21 \mu \mathrm{s})$ & OFF $(21 \mu \mathrm{s})$ & \\
\hline & $\mathrm{ON}(50 \mu \mathrm{s})$ & ON $(50 \mu \mathrm{s})$ & ON $(50 \mu \mathrm{s})$ & \\
\hline & PC (25 ampere) & PC (25 ampere) & PC (25 ampere) & \\
\hline $\begin{array}{l}\text { Material Removal Rate } \\
\left(\mathrm{mm}^{3} / \mathrm{min}\right)\end{array}$ & 27.45 & & 41.13 & increased $24.33 \%$ \\
\hline $\begin{array}{l}\text { Surface Roughness } \\
(\mu \mathrm{m})\end{array}$ & 4.63 & & 4.29 & decreased $5.89 \%$ \\
\hline
\end{tabular}

